the manufacture of chemicals by the contact process in dentistry and in jewellery."

Mr. Read was ordered abroad for active service while the volume was being set up. Had he seen all proofs, no doubt imperfections, of which the foregoing are random examples, would have been eliminated.

The book is a useful epitome of mineralogical principles and methods, and a convenient small work of reference to the more important rockforming and economic minerals.

C. G. C.

\section{British Sea Fish: An Illustrated Handbook of the} Edible Sea Fishes of the British Isles. By Harold Swithinbank and G. E. Bullen. Pp. xi +35 . (London: Simpkin, Marshall, Hamilton, Kent and Co., Ltd.) Price $2 s$. net.

THIs is a pamphlet of which six pages are devoted to an account of the British sea fisheries, and thirty-five pages to descriptions of some thirtyfour species of marketable fishes. The illustrations are very small half-tone reproductions of mediocre photographs. The descriptions consist each of about six to ten lines of print summarising the characters of the species; two or three lines of print giving the range of occurrence; and of "remarks" dealing mainly with the quality, flavour, and methods of cooking of the fishes considered. We learn from the preface that the work "is to be regarded as in no way scientific," and that it is intended to popularise the cheaper and coarser kinds of sea-fish which at present suffer from prejudice. Considering these limitations and the relatively high price of the pamphlet, we find it difficult to think of the particular public to which it is intended to appeal at the present time; for it is far too small to be of much use to anyone really interested in marine biology, and too expensive to be used in a propaganda.

J. J.

\section{LETTERS TO THE EDITOR.}

[The Editor does not hold himself responsible for opinions expressed by his correspondents. Neither san he undertake to return, or to correspond with the writers of, rejected manuscripts intended for this or any other part of NATURE. No notice is taken of anonymous communications.]

\section{"Summer Time" and Meteorology.}

Recently I have had occasionally to rise at $3 \mathrm{a} . \mathrm{m}$. and to be out between $3 \mathrm{a} . \mathrm{m}$. and $5 \mathrm{a} . \mathrm{m}$. I found the weather misty and relatively very cold, with temperature about $45^{\circ} \mathrm{F}$. Later in the day temperature rose to $75^{\circ} \mathrm{F}$. Clothing suitable for the early morning was quite unsuitable for the day, and (what I specially noticed) vice versa ; it occurred to me that civilised people had unconsciously adopted a day which centred a little later than the time of maximum temperature, thereby securing the nearest possible approach to a uniform temperature in the daily period of their "away from home" existence. In this way they save themselves unnecessary trouble in putting on and taking off clothing; and, further, they save themselves unnecessary risk of chills and colds. The change from a temperature of $45^{\circ} \mathrm{F}$. to one of $75^{\circ} \mathrm{F}$. is equivalent to changing from a cool day of January to a warm day of July. The change may stimulate and energise No. 2430 , VOL. 97$]$ the labourer in the fields; I doubt if its effect on the worker in a city office is good or pleasant.

The average increase of temperature from 8 a.m. to 9 a.m. in the summer months is nearly $4^{\circ}$ per cent. of the increase from 9 a.m. to the maximum about 2 p.m.; and the decrease in humidity (or dampness of the air) from 8 a.m. to 9 a.m. is nearly 50 per cent. of the decrease from 9 a.m. to the minimum humidity in the afternoon (and the rate of change from 7 a.m. to 8 a.m. is equally fast).

Moving the hands of the clock will neither warm nor dry the air. People are therefore being plunged into cooler, damper air through their ignorance (I) of the fact that custom is usually based on the teachings of experience; (2) of the facts of observation which indicate directly what has been the indirect teaching of experience in this case.

The argument that it is as cold in April at 9 a.m. as it is in May at $8 \mathrm{a} . \mathrm{m}$. is ineffective, because people in England adapt the amount and character of their clothing to the season of the year, and what they feel most is not absolute cold, but relative cold; and relatively to the middle of the day it is twice as cold at 8 a.m. in May as at 9 a.m. in January.

There is an element of romance about early rising if the experiment is not too often repeated. Perhaps one summer will suffice.

E. GOLD.

IN accordance with the provisions of the Summer Time Act, Greenwich Mean Time will continue to be used for all meteorological observations and publications, so that no discontinuity will be caused during the period when Summer Time is in force. But besides the observations which are made by regular observers, many meteorological phenomena of various kinds are from time to time recorded or reported, and it is highly desirable that there should be no ambiguity in these reports, which are often of much interest and importance. The council of the Royal Meteorological Society desires to direct attention to the necessity of stating precisely the time of occurrence in all such cases, and whether the times quoted refer to Greenwich Mean Time or to Summer Time, since the omission of this information may render the record of the phenomenon useless for meteorological purposes.

Such occasional observations form a valuable addition to those which are made at the permanent observing stations and supplement them usefully; it is therefore essential that they should be recorded with precision.

Royal Meteorological Society, May 19.

President

\section{Geologists and Special Constables.}

A RECENT experience of Canon E. Hill and myselt may be useful to geologists. On May 3 we went by train from Lincoln to East Barkwith Station, on the line to Louth, and walked by a rather roundabout route to South Willingham Station, looking at the structure of the country and for sections of drift. While waiting for our train outside the latter station, a man, in dress and aspect rather above a farm labourer, accompanied by another with a badge of some sort on his coat, came up to us, and in none too civil a tone began to catechise us as to what we were doing, where we were and had been staying, our homes, professions, ages, heights, and the like, about which we gave him full information. Apparently he did not know that there was such a science as geology, but after he had received a large amount of biographical information he acknowledged it by saying, in the tone of one rebulking two peccant villagers, that as 